\title{
31. 迅速処理用オルソフィルム(MGC-SR)の基礎的検討
}

\begin{tabular}{|c|c|c|c|}
\hline \multirow[t]{3}{*}{ 名古屋市立大学病院中央放射線部 } & ○樋口 & 原知恵 & 集本 吾一 \\
\hline & $\prod_{\substack{\text { Makoto Kawano) } \\
\text { (M) 諴 }}}$ & 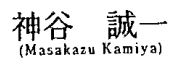 & 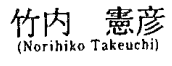 \\
\hline & 岩田 賢二 & 杉山 雅之 & 岩田 宏道 \\
\hline
\end{tabular}

【目的】当院では、胸部単純写真にオルソフィルムM G C を使用してきた。

今回、迅速処理用自現機コニカ S R X - 501が導入され、迅速処理用オルソフィルム M G C - S R を使用する機会を得た。徉来の胸部専用フィルムM G C と物理特性および臨床評価を比較、検討を行 ったので報告する。

【方法】(1)物理特性一特性曲線（管電圧 $70 \mathrm{~K} \mathrm{~V}$ 距離法）鮮鋭度

(2)臨床評価一放射線科医 5 名に各所見について読影を依頼

(3)比較するフィルムと自現機の種類(1) M G C /フジF P M 4000(2)M G C - S R /コニカ S R X 501 (90 S / 現像温度 $32^{\circ} \mathrm{C}$ ) (3) M G C - S R /コニカS R X 501 (45 S / 現像温度 $35^{\circ} \mathrm{C}$ )

【結果及び考察】特性曲線をFig 1 に示す。従来のM G C に 比較して、M G C - S R 90秒処理は朋の部分と肩の部分が上 がっている。M G C-S R 45秒処理は、M G C-S R 90秒処 理よりガンマーが低く、感度も約 $20 \%$ 程低い。M T F を Fig 2 に示す。MG C-S R、M C Cの順で優れている。90秒処 理と45秒処理の差はほとんどない。R M S 粒状度をFig 3 に 示す。M G C - S R 90秒妈理はM G C と比較して高濃度域で は優れている。45秒処理は、他の 2 種類に比べて全ての濃度 域で、特に優れている。

臨床評価をTable 1 に示す。胸部単純正面像10例（肺癌 3 例） で比較した。それぞれの所見について識別は出来るが不明瞭 は 1 点、良く識別出来るは 2 点、非常に明瞭に描出されてい るは 3 点の 3 段階で点数評価を行い、その点数を所見別、フ イルム別に全症例加算した。フィルムベースの色調が違って いるが、M G C-S R はM G C と比較して縦隔㓌影は優れ、 さらに肺血管影や気道系もほぼ同等の評価である。

以上より、M G C - S R は胸部専用フィルムとして有用なも のと考える。45秒処理については、感度が約 $20 \%$ 低いことに より、現在の撮影システムでは、撮影時間が長くなる懸念が あるが、今後感度 の高い増感紙を使 用して従来の胸部 専用フィルム $\mathrm{M} \mathrm{G}$ Cと同じ画質を得 られるかどうかの 検討を加え、45秒 現像処理に移行し ていきたいと考え ている。

\begin{tabular}{|c|c|c|c|c|}
\hline & 网数 & $\begin{array}{c}\text { MG C } \\
\text { FPM4000 }\end{array}$ & $\begin{array}{r}\text { MGC-SR } \\
\text { SRX501 } 805\end{array}$ & $\begin{array}{c}\text { MGC-SR } \\
\text { SRK501 } 455\end{array}$ \\
\hline 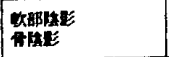 & 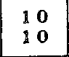 & $\begin{array}{r}108 \\
81 \\
81\end{array}$ & $\begin{array}{r}10 \\
8 \\
89\end{array}$ & $\begin{array}{r}106 \\
99\end{array}$ \\
\hline 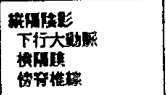 & $\begin{array}{ll}1 & 0 \\
1 & 0 \\
1 & 0\end{array}$ & $\begin{array}{r}97 \\
113 \\
83\end{array}$ & $\begin{array}{r}104 \\
115 \\
115 \\
94 \\
\end{array}$ & $\begin{array}{r}108 \\
119 \\
92 \\
92\end{array}$ \\
\hline 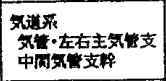 & $\begin{array}{ll}1 & 0 \\
10\end{array}$ & $\begin{array}{r}135 \\
92\end{array}$ & $\begin{array}{r}113 \\
92\end{array}$ & $\begin{array}{r}184 \\
98\end{array}$ \\
\hline 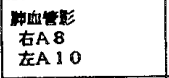 & $\begin{array}{l}10 \\
10\end{array}$ & $\begin{array}{l}87 \\
87\end{array}$ & $\begin{array}{l}92 \\
90\end{array}$ & $\begin{array}{l}87 \\
88\end{array}$ \\
\hline 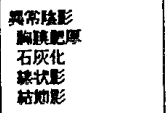 & $\begin{array}{l}4 \\
3 \\
6 \\
4\end{array}$ & $\begin{array}{l}43 \\
28 \\
60 \\
40 \\
40\end{array}$ & $\begin{array}{l}42 \\
25 \\
55 \\
41 \\
\end{array}$ & $\begin{array}{l}47 \\
21 \\
56 \\
44 \\
\end{array}$ \\
\hline
\end{tabular}

Table 1

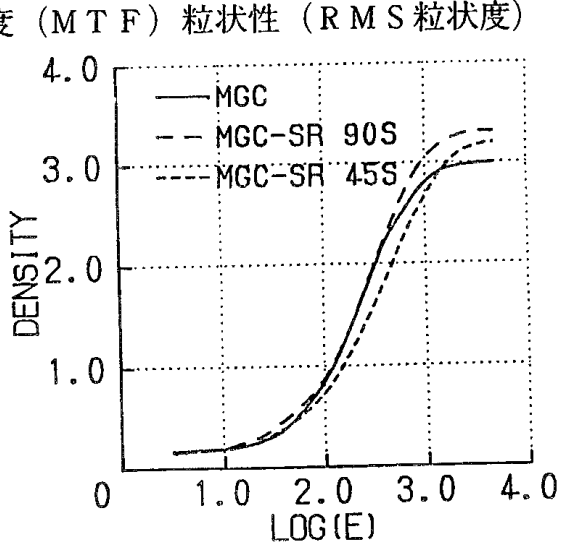

Fig 1

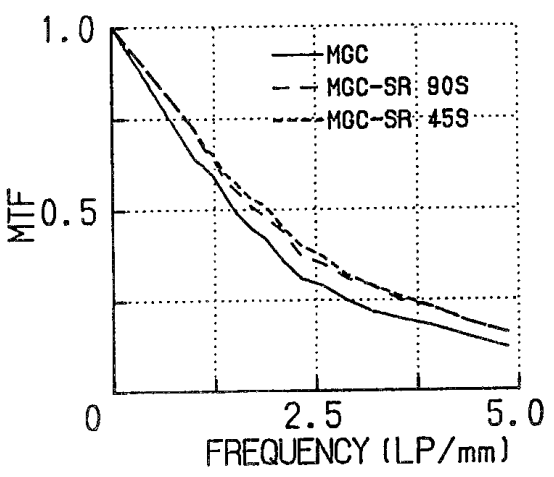

Fig 2

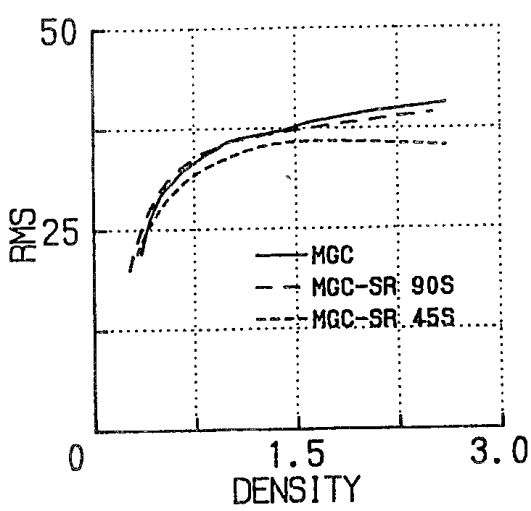

Fig 3 